DOI: http://dx.doi.org/10.21123/bsj.2016.13.4.0838

\title{
Synthesis, Spectral and Dyeing Performance Studies of 4-(2- Aminmo-5-nitro-phenylazo)-1,5-dimethyl-2-phenyl-1,2- dihydro-pyrazol-3-one Complexes with Some Metal Ions
}

\begin{abstract}
Amer J. Jarad
Department of Chemistry, College of Education for Pure Science /Ibn-Al-Haitham University of Baghdad, Adhamiyah-Anter Square, Baghdad- IRAQ

Received 24/5/2015

Accepted 21/12/2016

(1) $(9)$

EY NG No This work is licensed under a Creative Commons Attribution$\underline{\text { NonCommercial-NoDerivatives 4.0 International Licens }}$

Abstract:

The ligand 4-(2-aminmo-5-nitro-phenylazo)-1,5-dimethyl-2-phenyl-1,2dihydro-pyrazol-3-one derived from 4-aminoantipyrine and 4-nitroaniline was synthesized. The synthesized ligand was characterized by ${ }^{1}$ HNMR, FT-IR, UV-Vis spectra and (C.H.N) analysis. Complexes of ( $\mathrm{Y}^{\mathrm{III}}$ and La ${ }^{\mathrm{III}}$ ) with the ligand were prepared in aqueous ethanol with a 1:2 M:L ratio and at optimum $\mathrm{pH}$. The prepared complexes were characterized by using flame atomic absorption, FT-IR, UV-Vis spectra,(C.H.N) analysis and conductivity measurement. The stoichiometry of complexes was studied by the mole ratio and job methods. A concentration range $\left(1 \times 10^{-4}-3 \times 10^{-4} \mathrm{M}\right)$ obeyed Beer's law, the complex solutions show high values of molar absorption. On the basis of physicochemical data octahedral geometries were attributed for the complexes. All prepared compounds exhibited good antibacterial activity, the ligand and their complexes were application to cotton fabric and study of the detergent fastness.
\end{abstract}

Key words: Complexes, Synthesis of Dyes, Biological Activity

\section{Introduction:}

Pyrazoles and their derivatives are interesting as potential pharmaceuticals and intermediates in dye industry, among their derivatives are compounds which azo exhibited a wide variety of biological and pharmaceutical activities and therefore play important role in medicinal chemistry [1-5]. Azo dyes are a class of chemical compounds that are continuously receiving attention in scientific research [6]. Therefore they are used in different application fields, such as medicines, cosmetics, food paints, plastics, shipbuilding and automobile industry [7]. Recently, complexes of azo dyes appeared great attention due to their grave electronic and geometrical structures in connection with their application for molecular memory storage, nonlinear optical elements and printing systems [8]. 


\section{Materials and Methods:}

All chemicals used were of reagent grade and used without further purification $\mathrm{LaCl}_{3} .9 \mathrm{H}_{2} \mathrm{O}$ and $\mathrm{Y}(\mathrm{NO} 3)_{3}$. $5 \mathrm{H}_{2} \mathrm{O}$ (Merck),4-aminoantipyrine and 4nitroaniline (B.D.H).

FT.IR- spectra as $\mathrm{KBr}$ discs, in the range (4000 - 400) $\mathrm{cm}^{-1}$ were obtained using a Shimadzu, FT.IR-8400S Fourier Transform Infrared Spectrophotometer. Spectra were recorded in ethanol $10^{-3} \mathrm{M}$ using Shimadzu UV-160A Ultra VioletVisible Spectrophotometer. The (C.H.N) analysis was performed in the central service laboratory, College of Education for pure Sciences/Ibn Al-haitham by using (Euro EA 3000 Elemental Analyzer. Conductivities were measured for $10^{-3} \mathrm{M}$ of complexes in etanol at $25^{\circ} \mathrm{C}$ by using (Philips PW- Digital Conductimeter). Atomic Absorption was obtained by using a (Shimadzu A.A160A) Atomic Absorption/Flame Emission Spectrophotometer. The ${ }^{1} \mathrm{H}-$ NMR spectra were recorded on a Brucker-300 MHz Ultra Shield spectrometer at the University of Al- alBayt using DMSO as the solvent and TMS as the reference. Melting points have been gained by using Stuart Melting Point Apparatus.

\section{Preparation of the 2-(4-antipyrine} azo)-4-nitroaniline ligand $(L)$ [9]

A solution of 4-aminoantipyrine $(0.50 \mathrm{~g}, 1 \mathrm{mmole})$ in $(10 \mathrm{ml})$ of $\mathrm{EtOH}$ containing $(2 \mathrm{ml})$ conc. $\mathrm{HCl}$ which was diluted with $10 \mathrm{ml} \mathrm{H}_{2} \mathrm{O}$ was prepared, and diazotized at $5^{\circ} \mathrm{C}$ with $10 \%$ solution of $\mathrm{NaNO}_{2}$. The diazo compound was added gradually with stirring to a cooled aqueous ethanol of $(0.34 \mathrm{~g}, 1 \mathrm{mmole})$ of 4-nitoaniline. The solution of sodium hydroxide (1M) was added to the mixture; the precipitation was observed and filtered, washed several times to (1:1) ethanol: water, then let to dry in a desicater. The preparation steps are represented in scheme 1 , while the physical properties together with elemental analysis are represented in Table 1.

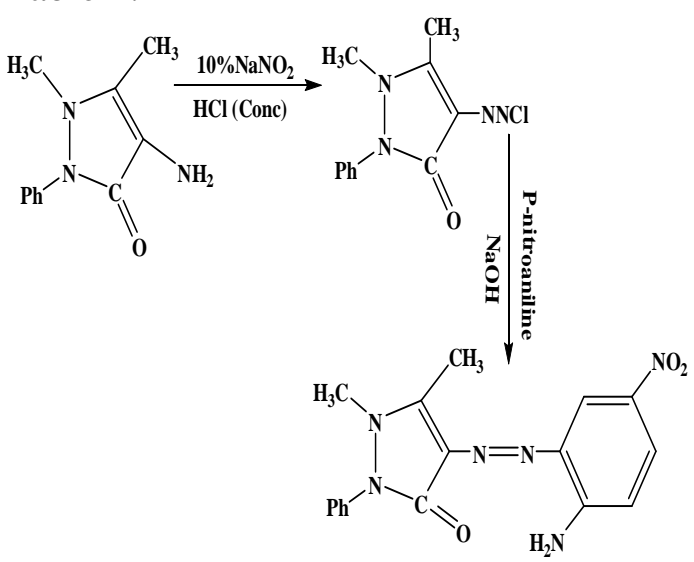

Scheme (1): Synthesis of the Azo Ligand (L).

\section{Buffer Solution}

$(0.01 \mathrm{M}, \quad 0.771 \mathrm{gm})$ of ammonium acetate was dissolved in one liter of doubly deionized water. For adjusted $\mathrm{pH}$ range (4-8) was used acetic acid or ammonia solution.

\section{Standard Solution}

A series of standard solutions of $\mathrm{Y}\left(\mathrm{NO}_{3}\right)_{3} \cdot 9 \mathrm{H}_{2} \mathrm{O}$ and $\mathrm{LaCl}_{3} \cdot 6 \mathrm{H}_{2} \mathrm{O}$ were prepared in different concentration $\left(10^{-}\right.$ $\left.{ }^{5}-10^{-3} \mathrm{M}\right)$ at $\mathrm{pH}$ range (4-8). At the same time a series of ethanolic solutions of ligand within the range of concentrations $\left(10^{-5}-10^{-3} \mathrm{M}\right)$ were also prepared.

\section{Dyeing Method}

The prepared compounds were examined for their dyeing properties at Fine Textile State Company in Hilla, using the Azoic Dyes Method. The compounds were used as dyes on cotton fabric as $1 \%$ shade, at $15-20{ }^{\circ} \mathrm{C}$ for 1 hour and $\mathrm{pH}$ equals 10 .

\section{Study of Biological Activity}

The antibacterial activity for these by using method compounds was evaluated similar with the traditional disc diffusion method, sterile $5 \mathrm{~mm}$ filter paper discs (Whatman,no.1) were soaked in this compound (Disc loaded with the DMSO as a solvent and as a 
control) and allowed until complete evaporation to be used. Then discs were placed onto the surface of the Muller Hinton agar plates at different areas on the surface of each plate, after a $24 \mathrm{hr}$ culture of the pathogenic strains (E.Coli,Staph .aurous and Ps. aeruginosa) were spreading over the surface of Muller Hinton agar plates with a sterile cotton swab. The plates were incubated at $37 \mathrm{C}^{\circ}$ for $24 \mathrm{hr}$. Results were indicated by recording the diameter $(\mathrm{mm})$ for a zone of inhibition around each disc on the plate.

\section{Preparation of Metal Complexes (general procedure)}

The complexes were prepared by adding gradually with stirring hot ethanolic solution of (2mmole) of ligand to stoichiometric amount of $(1: 2)(\mathrm{M}: \mathrm{L})$ mole ratio (1mmole) of $\mathrm{Y}\left(\mathrm{NO}_{3}\right)_{3} \cdot 9 \mathrm{H}_{2} \mathrm{O}$ and $\mathrm{LaCl}_{3} \cdot 6 \mathrm{H}_{2} \mathrm{O}$ were dissolved in the buffer solution at optimum $\mathrm{pH}$. The resultant mixture was heated at $\left(60^{\circ} \mathrm{C}\right)$ with stirring for $(2 \mathrm{hr})$, then left to cool to room temperature. The colored precipitates were filtered, washed and dried in vacuum desicator. The expected stereochemical structure of the complex is shown in Scheme (2).

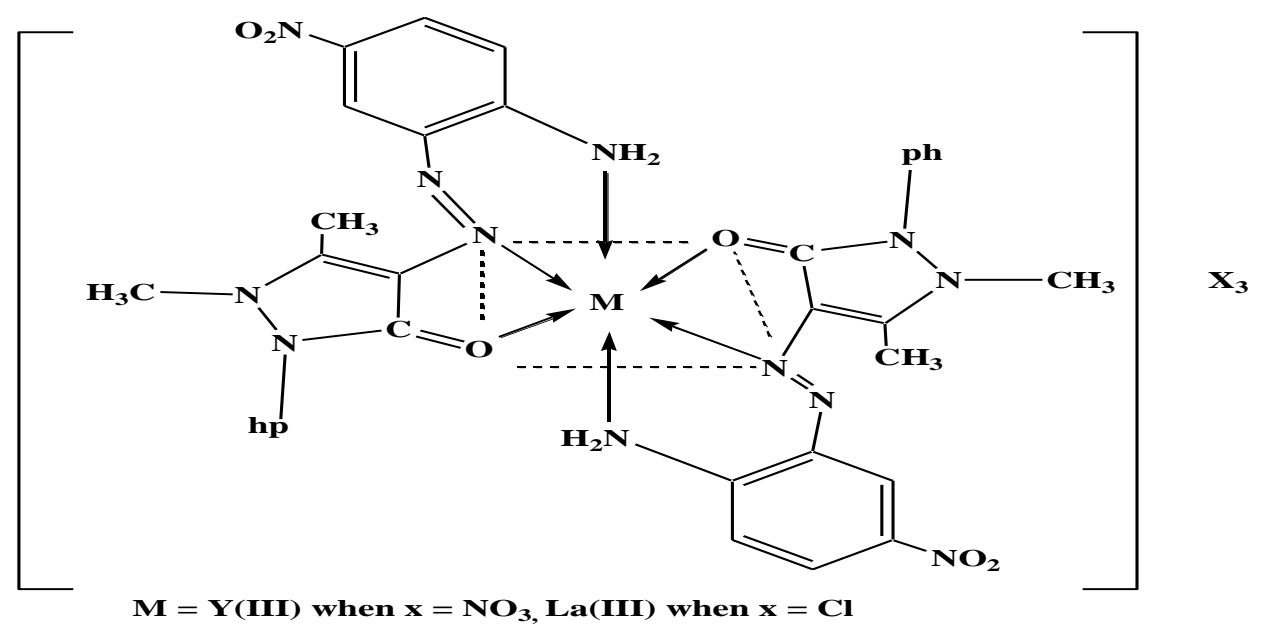

Scheme (2): The Expected Structure of the Complexes.

Table (1): Physical properties and elemental analysis of the ligand and its complexes.

\begin{tabular}{|c|c|c|c|c|c|c|c|}
\hline \multirow{2}{*}{ Compounds } & \multirow{2}{*}{ Color } & \multirow{2}{*}{ M.P'C } & \multirow{2}{*}{ Yield\% } & \multicolumn{4}{|c|}{ Analysis Calc (Found) } \\
\cline { 5 - 8 } & & & $\mathbf{M} \%$ & $\mathbf{C} \%$ & $\mathbf{H} \%$ & $\mathbf{N \%}$ \\
\hline Ligand(L) & $\begin{array}{c}\text { Reddish } \\
\text { Brown }\end{array}$ & 180 & 76 & - & $\begin{array}{c}57.95 \\
(57.26)\end{array}$ & $\begin{array}{c}4.54 \\
(3.97)\end{array}$ & $\begin{array}{c}23.86 \\
(22.75)\end{array}$ \\
\hline$\left[\mathrm{Y}(\mathrm{L})_{2}\right]\left(\mathrm{NO}_{3}\right)_{3}$ & Orange & 274 & 88 & $\begin{array}{c}9.09 \\
(8.83)\end{array}$ & $\begin{array}{c}41.67 \\
(40.98)\end{array}$ & $\begin{array}{c}3.26 \\
(2.85)\end{array}$ & $\begin{array}{c}17.16 \\
(16.93)\end{array}$ \\
\hline$\left[\mathrm{La}(\mathrm{L})_{2}\right] \mathrm{Cl}_{3}$ & Red & 238 & 81 & $\begin{array}{c}14.63 \\
(13.86)\end{array}$ & $\begin{array}{c}42.96 \\
(41.93)\end{array}$ & $\begin{array}{c}3.37 \\
(2.77)\end{array}$ & $\begin{array}{c}17.69 \\
(16.83)\end{array}$ \\
\hline
\end{tabular}

\section{Results and Discussion:}

For the preparation of the ligand (L) a coupling of 4-nitroaniline with the appropriate diazotized in alkaline solution was carried out. The solubility of the ligand was investigated and was found to be soluble in organic solvents and was stable toward air and moisture. Synthesized ligand was characterized by
(C.H.N) analysis, ${ }^{1}$ H-NMR,FT-IR and UV-Vis spectroscopy. The ${ }^{1} \mathrm{H}-\mathrm{NMR}$ spectrum of the ligand in DMSO (Fig.1) appear multiplet signals at $\delta=7.426$ $7.967 \mathrm{ppm}$ due to aromatic protons [10]. The signals at $\delta=2.368 \mathrm{ppm}$ and $\delta=1.176$ ppm were assigned to $\delta\left(\mathrm{N}-\mathrm{CH}_{3}\right)$ and $\delta\left(\mathrm{CH}_{3}\right)$ of pyrazole[11]. The signal at $\delta=3.441$ ppm was ascribed to $\delta\left(\mathrm{NH}_{2}\right)$ 
and the signal at $\delta=2.50 \mathrm{ppm}$ referred to DMSO- $\mathrm{d}_{6}[12]$.

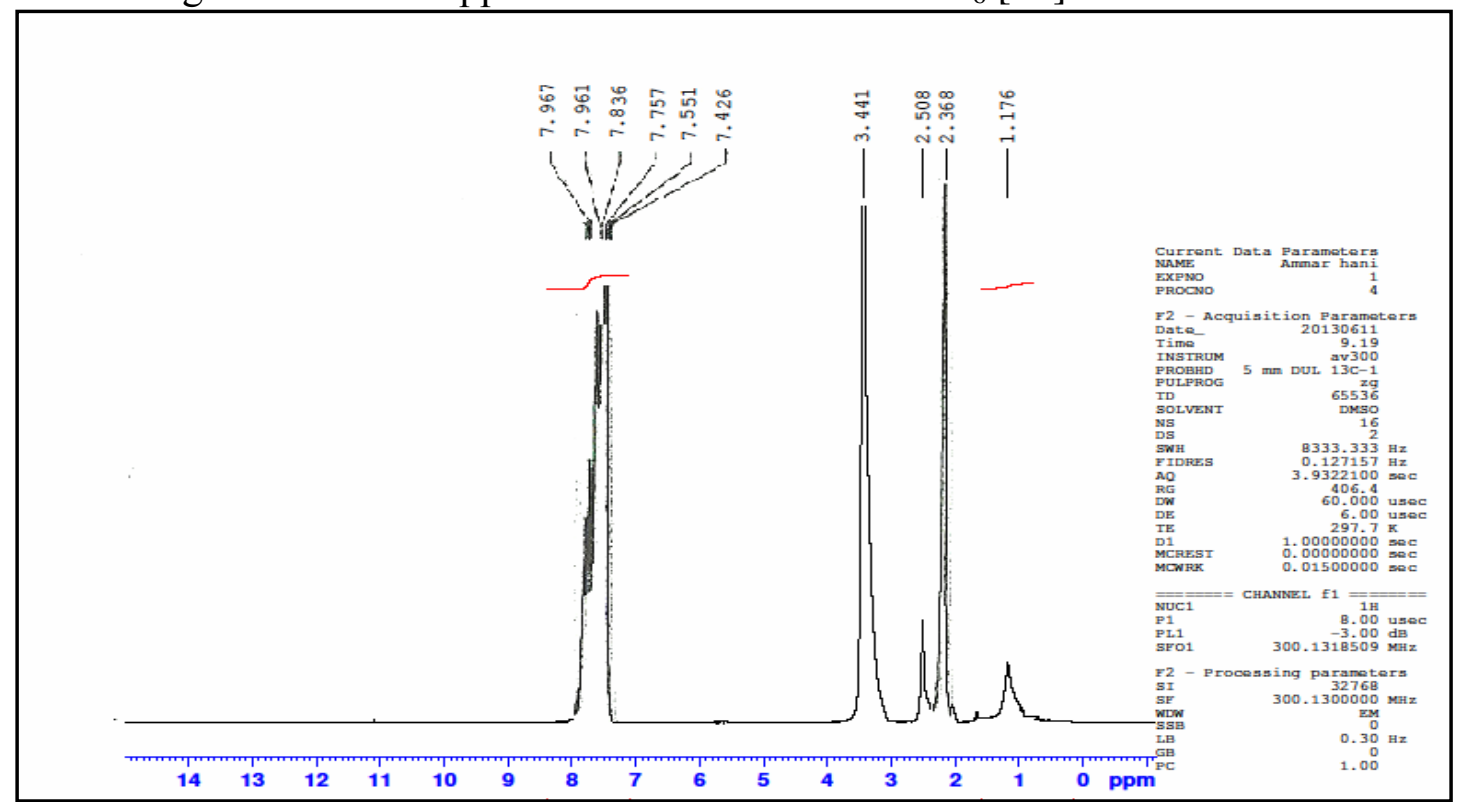

Fig. (1): ${ }^{1}$ H-NMR Spectrum of the Azo Dye Ligand (L).

An aqueous-ethanolic solutions were always performed to study the interaction of the metal ions Y(III) and $\mathrm{La}(\mathrm{III})$ with the prepared ligand. The colors of these mixed solutions over the molar concentration and acidity range performed were varied from orange to red.

Different range of molar concentrations $\left(10^{-5}-10^{-3} \mathrm{M}\right)$ of the mixed solutions were studied, only concentrations in the range of $10^{-4} \mathrm{M}$ obeyed the Lambert- Beer's law, and only these solutions showed intense color. A calibration curve was fitted to data points in the range $1 \times 10^{-4}-3 \times 10^{-4}$ $\mathrm{M}$, which shows absorbance against molar concentration (Fig.-2). Best fit straight lines were obtained with correlation factor of $\mathrm{R}>0.998$.

The optimal concentration was chosen for complex solutions, and it was observed that the absorption maximum $\left(\lambda_{\max }\right)$ remained the same at different $\mathrm{pH}$ values. The influence of $\mathrm{pH}$ was also studied in the $\mathrm{pH}$ range of $4-8$, and the absorbance- $\mathrm{pH}$ curves for each metal ion measured at $\lambda_{\max }$ are plotted in (Fig.3), shows selective $\mathrm{pH}$-absorbance curves. The plateaus of the curves represent the completion of the reaction and consequently represent the optimum $\mathrm{pH}$ value.

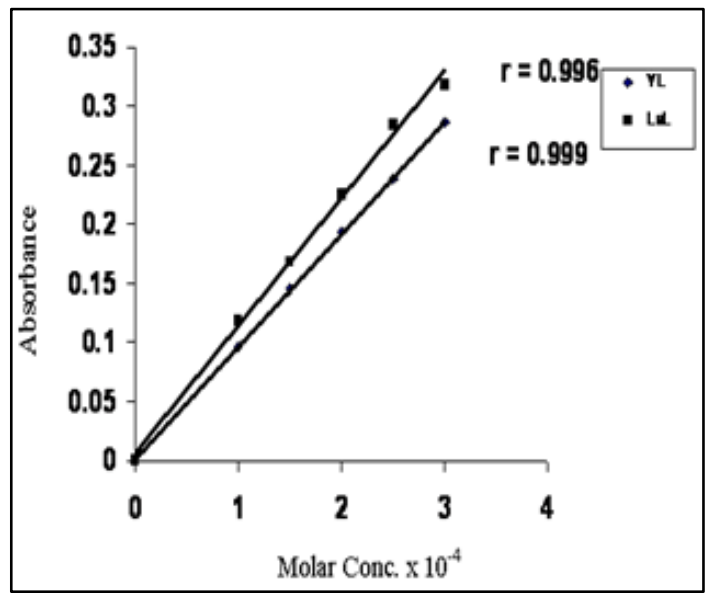

Fig. (2): Linear Relation between Molar concentration and absorbance. 


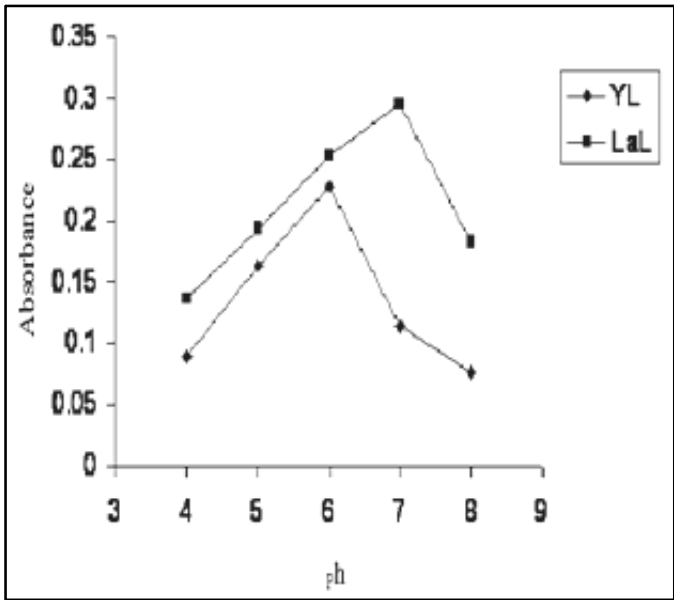

Fig. (3): Effect of pH on bsorbance $\left(\lambda_{\max }\right)$ for complexes.

Both mole ratio and job methods were performed in solution to determine the composition of the prepared complexes. The results show a 1:2 metal: ligand ratio for the two methods. Fig.- 4 dominstates a selected plot, while Table 2 shows the complexes preparation conditions.

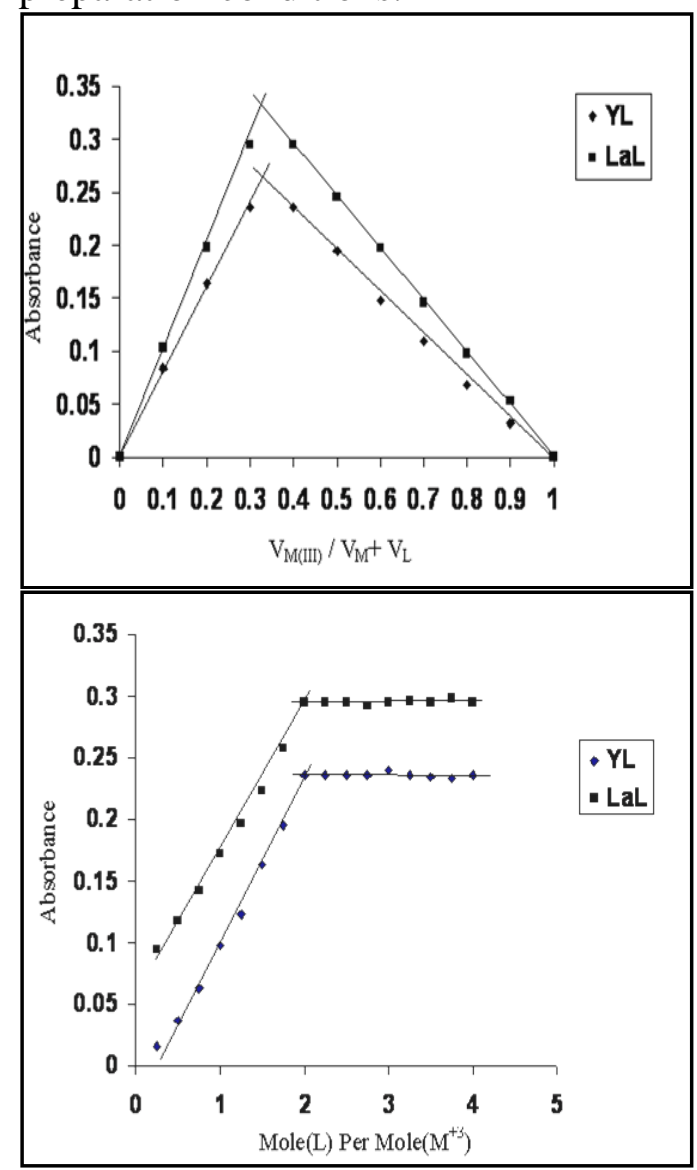

Fig. (4): Mole Ratio and Job Methods for Complexes Solutions.
The complexes were prepared by reaction of ethanolic solution of the ligand with the metal ions dissolved in optimum $\mathrm{pH}$ at $\mathrm{M}: \mathrm{L}$ ratio of $1: 2$. The (C.H.N) analysis and metal content data of the prepared compounds are in good convention with the calculated result from expected formula of each synthesized. The conductivity measurements in ethanol $10^{-3} \mathrm{M}$ at $25^{\circ} \mathrm{c}$ indicated the electrolytic type [13] ratio 1:3; data are presented in Table 2.

The UV- Vis spectrum of an ethanolic solution of the ligand $\left(10^{-3}\right.$ M) shows peaks, the first and second peaks were observed at 259 and $295 \mathrm{~nm}$ due to $\pi-\pi^{*}$ electronic transition of the aromatic rings. The third peak was observed at the $425 \mathrm{~nm}$ referred to the $\mathrm{n}$ $\pi^{*}$ transition of intermolecular chargetransfer taken place from benzene through the azo group $(-\mathrm{N}=\mathrm{N})[14]$. Table 2 represents the measured data obtained from the UV-Vis spectra of all prepared complexes which were dissolved in ethanol and made to $\left(10^{-3}\right.$ $\mathrm{M})$. The large bathchromic shift of the $\left(n-\pi^{*}\right)$ transition of the ligand, suggests the participation of the ligand in the bond formation with the metal ion. 
Table (2): Conditions for the Preparation of the Complexes and UV-Vis, Conductance Measurements Data.

\begin{tabular}{|c|c|c|c|c|c|c|c|}
\hline Compounds & $\begin{array}{c}\text { Optimum } \\
\text { pH }\end{array}$ & $\begin{array}{c}\text { Optimum } \\
\text { Molar Conc. } \\
\times 10^{-4} \\
\end{array}$ & $\begin{array}{l}\text { M:L } \\
\text { Ratio }\end{array}$ & $\begin{array}{c}\left(\lambda_{\max }\right) \\
\mathrm{nm}\end{array}$ & ABS & $\underset{\left(\mathbf{L} \cdot \mathrm{mol}^{-1} \cdot \mathrm{cm}^{-1}\right)}{\boldsymbol{G}_{\max }}$ & $\begin{array}{c}\Lambda_{\mathrm{m}}\left(\mathrm{S} \cdot \mathrm{cm}^{2} \cdot \mathrm{mol}^{-1}\right) \mathbf{I n} \\
\text { Absolute ethanol }\end{array}$ \\
\hline Ligand(L) & - & - & - & 425 & 0.879 & 879 & - \\
\hline$\left[\mathrm{Y}(\mathrm{L})_{2}\right]\left(\mathrm{NO}_{3}\right)_{3}$ & 6 & 2 & $1: 2$ & 482 & 1.451 & 1451 & 117.42 \\
\hline$\left[\mathrm{La}(\mathrm{L})_{2}\right] \mathrm{Cl}_{3}$ & 7 & 2 & $1: 2$ & 475 & 1.620 & 1620 & 120.23 \\
\hline
\end{tabular}

The FT-IR spectral data of the ligand and all complexes are listed in Table-2. The IR spectrum of the ligand exhibited bands at 3388 and $3377 \mathrm{~cm}^{-}$ 1 ascribed to the $v\left(\mathrm{NH}_{2}\right)$ stretching vibration [15], on coordination with metal ion, these bands were observed with a high change in the shape and locale. Strong band at $1716 \mathrm{~cm}^{-1}$ in the ligand spectrum referred to $v(\mathrm{C}=\mathrm{O})$ vibration, change in the intensity and in position to lower frequency observed on coordination with metal ion [16]. The strong characteristic band at $1567 \mathrm{~cm}^{-1}$ which was assigned to the $(-\mathrm{N}=\mathrm{N}-)$ stretching, on complexation a great change in position was happened to lower frequency, which is an indication of the engagement of this group in the coordination with the metal ion $[17,18]$. Stretching frequency bands for metalnitrogen and metal-oxygen further confirmed by the presence of the bands around $440-547 \mathrm{~cm}^{-1}[19,20]$.

Table (3): The Main Frequencies of the Ligand and its Complexes $\left(\mathrm{cm}^{-1}\right)$.

\begin{tabular}{|c|c|c|c|c|c|}
\hline Compounds & $v\left(\mathrm{NH}_{2}\right)$ & $v(\mathrm{C}=\mathrm{O})$ & $\begin{array}{c}v(-\mathrm{N}=\mathrm{N}- \\
)\end{array}$ & $\begin{array}{c}v(\mathrm{M}- \\
\mathrm{N})\end{array}$ & $\begin{array}{c}v(\mathrm{M}- \\
\mathrm{O})\end{array}$ \\
\hline Ligand(L) & $\begin{array}{c}3388 \mathrm{~b} \\
3377 \mathrm{~b}\end{array}$ & $\begin{array}{c}1716 \\
\text { sh. }\end{array}$ & $1567 \mathrm{~s}$. & - & - \\
\hline$\left[\mathrm{Y}(\mathrm{L})_{2}\right]\left(\mathrm{NO}_{3}\right)_{3}$ & $3462 \mathrm{~b}$ & $1680 \mathrm{~s}$. & $1521 \mathrm{~s}$. & $\begin{array}{c}547 \\
\text { w. }\end{array}$ & $\begin{array}{c}462 \\
\text { w. }\end{array}$ \\
\hline$\left[\mathrm{La}(\mathrm{L})_{2}\right] \mathrm{Cl}_{3}$ & $3446 \mathrm{~b}$ & $1683 \mathrm{~s}$. & $1517 \mathrm{sh}$. & $\begin{array}{c}528 \\
\text { w. }\end{array}$ & $\begin{array}{c}440 \\
\text { w. }\end{array}$ \\
\hline
\end{tabular}

$\mathrm{b}=$ broad; $\mathrm{s}=$ strong; $\mathrm{sh}=$ sharp $\mathrm{w}=$ weak

The performance of the prepared compounds towards dyeing on cotton fabric was examined. The dyes were examined for stability towards light and detergents and showed very good dyeing properties.

All the prepared compounds have been examined with Gramnegative and Gram-positive bacteria for the presence of antibacterial constituents, by using disc diffusion method. The data are recorded in Table 4. The results explained that the lanthanum complex has a relatively strong deactivating capacity.

Table (4): Diameters ( $\mathrm{mm})$ of Deactivation of Bacteria for the Ligand and its Complexes.

\begin{tabular}{|c|c|c|c|}
\hline Compounds & $\begin{array}{c}\text { Staphylococcus } \\
\text { aurous }\end{array}$ & $\begin{array}{c}\text { Escherichia } \\
\text { Coli }\end{array}$ & $\begin{array}{c}\text { Pseudomonas } \\
\text { aeruginosa }\end{array}$ \\
\hline Ligand $(\mathrm{L})$ & + & - & + \\
\hline$\left[\mathrm{Y}(\mathrm{L})_{2}\right]\left(\mathrm{NO}_{3}\right)_{3}$ & ++ & - & ++ \\
\hline$\left[\mathrm{La}(\mathrm{L})_{2}\right] \mathrm{Cl}_{3}$ & + & + & ++ \\
\hline
\end{tabular}

$(-)=$ No inhibition; $(+)$ =Inhibition diameter(68) $\mathrm{mm} ;(++)=$ Inhibition diameter $(8-10) \mathrm{mm}$.

\section{References:}

[1] Rajendran, S. P. and Karvembu, B. 2002. Synthesis and Antifungal Activities of Schiff Bases Derived from 3-Amino-2H-Pyrano [2,3b]quinolin-2-ones, Indian. J. Chem. 41B:222-224.

[2] Abadi, A. H.; Eissa, A. A. and Hassan, G. S. 2003. Synthesis of Novel 1,3,4-Trisubstituted Pyrazole Derivatives and Their Evaluation as Antiumor and Anti-antigenic Agents, Chem. Pharm. Bull. 51(7):838-844.

[3] Thakor, S. F.; Patel, D. M.; Patel, M. P. and Patel, R. G. 2007. Synthesis and Antibacterial Activity Novel Pyrazoles [3,4-b] Quinoline Based Heterocyclic Azo Compounds and Their Dyeing Performance, Saudi. Pharm. J. 15(1):48-64.

[4] Thakare, N. R.; Dhawas, A. K.; Ganoskar, P. S. and Kale, P. D. 2012. Synthesis, Characterization of Some 3,5-dimethyl Azo Pyrazoles and Its Derivatives, J. Chem. Pharm. Res. 4(6):3329.3332. 
[5] Shukla, M.; Seth, D. S. and Kulshreshtha, H. 2013. Geen Chemical Approach to Synthesize 1(N-Substituted aniline malonyl)-3,5Dimetheyl-4-(3,4-Difluoro phenyl azo) Pyrazols and Their Antimicrobial Evaluation, J. Appl. Chem. 2(6): 1484-1488.

[6] Otutu, J. O. 2013. Synthesis and Application of Azo Dyes Derived from 2-amino1,3,4-thiadiazole-2thiol on Polyester Fibre, IJRRAS. 15(2):292-296.

[7] Al-Mousway, Z. A.; Khmas, B. W. and Jarad, A. J. 2013. Snthesis, Characterization of New Azo Compounds and Studies Effect on the Ach enzyme (invitro), Inter. J. Eng. Sci. Res. Tech. 2(2):959-967.

[8] Yildiz, E. and Boztepe, H. 2002. Synthesis of Novel Acidic Mono Azo Dyes and an Investigation of Their Use in the Textile Industry, Turk. J. Chem. 26:897-903.

[9] Kirkan, B. and Gup, R. 2008. Synthesis of New Azo Dyes and Copper(II) Complexes Derived from Barbituric Acid and 4Aminobenzoylhydrazone, Turk. J. Chem. 32:9-17.

[10] Carballo, R.; Castineiras, A.; Covelo, B.; Niclos, J. and VazqesLopez, E. M. 2001. Synthesis and Characterization of Potassium Complex of magneson: $\left[\mathrm{K}(\mathrm{HL})(\mathrm{OH})_{2}\right] \quad\left[\mathrm{H}_{2} \mathrm{~L}=4-(4-\right.$ nitrophenylazo) -resorcinol], Polyhedron. 20:2415-2420.

[11] SI, Y.; Hu, Q.; Huang, Z.; Yang, G. and Yin, J. 2005. Color Reaction of 2-(2-Quinolylazo)-5Dimethylaminoaniline with Palladium and its Application, Turk. J. Chem. 29:135-140.

[12] Pal, S. and Sinho, C. 2001. Studies on the Reactivity of cis$\mathrm{RuCl}_{2}$ Fragment in $\mathrm{Ru}\left(\mathrm{pph}_{3}\right)_{2}$ (TaiMe) $\mathrm{Cl}_{2}$ with $\mathrm{N}, \mathrm{N}$-chelators (Taime=1-Methyl-2-(p-Tolylazo) Imidazole). Spectral and
Electrochemical Characterization of the Products, Proc. Indian. Acad. Sci. 113(2):173-182.

[13] Geary, W. J. 1971. Characterization of Coordination Compounds, Coord. Chem .Rev. 7(1):81-122.

[14] Anita, K. R.; Reddy, V. and Rao, V. 2011. Synthesis and Antimicrobial Evaluation of Metal (II) Complexes of a Novel bisazo Dye 2,2 $2^{-}$[benzene-1,3-diyl $\operatorname{di}(\mathrm{E})$ diazene 2,1-diyl] bis(4-chloraniline); J. Chem. Pharm. Res. 3(3):511-519.

[15] Dharmalingam, V.; Ramasamy, A. K. and Balasuramanian, V. 2011. Synthesis and ESR Studies of Copper Metal Complexes of Dyes Derived from Remazol Red B, Procino Yellow, Fast Green FCF, Brilliant Cresyl Blue with Copper Acetate Monohydrate, E. J. Chem. 8(S1): S211-S224.

[16] Nair, M. L. H.; Mathew, G. and Kumar, M. R. S. 2005. Synthesis and Characterization of Some New $\mathrm{Cu}$ (II) Complexes of Azo Dyes Derived from 1,2-dihydro-1,5dimethyl-2-phenyl-4-amino-3H-

Pyrazole-3-one, Indian. J. Chem. 44A:85-89.

[17] Chauhan, M. B.; Bhoi, D. K.; Machhar, M. T.; Solanki, D. K. and Solanki, D. Synthesis, Characterization and Mesomorphic Properties of Azoester Mesogens: 4$\mathrm{N}$-alkoxybenzoic acid 4-[3(benzyliden- amino) -phenylazo]phenyl ester, Der. Pharm. Chemica. 2(4):30-37.

[18] Al-Hamdani, A. A. S. and Hassan, S. S. 2015. Synthesis, Characterization, Thermal Analysis and Structural Studies of New Complexes with Tetradentate Ligand, J. Baghdad for Sci. 12(2):379-393.

[19] Hakim, A. A.; Ahmed, A. and Benguzzi, S. A. 2008. Synthesis and Characterization of Some Transition 
Metals Complexes of Schiff Base Derived From Benzidine and Acetyl acetone, J. Sci. App. 2(1):83-90.

[20] Rajavel, R.; Vadivu, M. S. and Anitha, C. 2008. Synthesis, Physical
Characterization and Biological Activity of Some Schiff Base Complexes, E. J. Chem. 5(3): 620626.

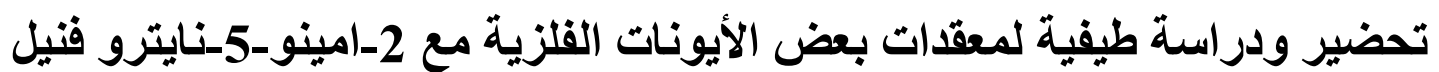

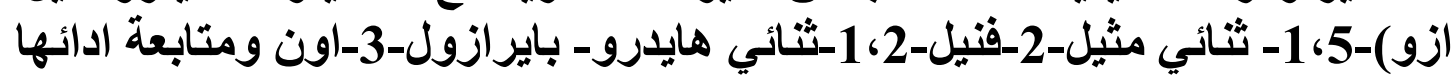 كصبغات
}

\author{
عامر جبار جراد
}

قسم الكيمياء، كلية التربية للعلوم الصرفة( ابن الهيثم)، جامعة بغداد

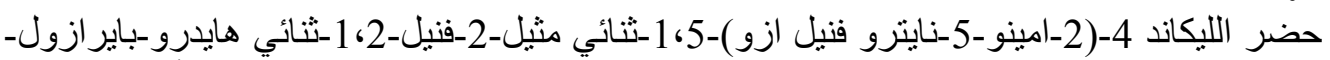

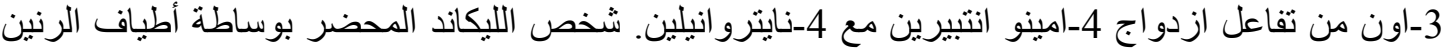

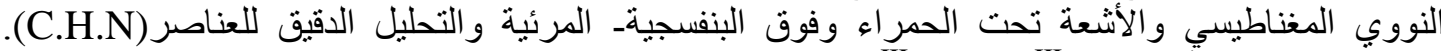

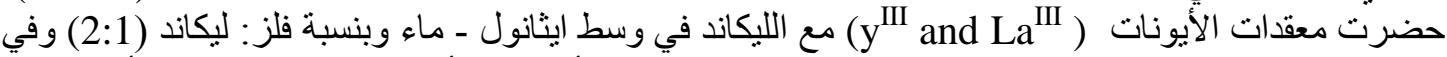

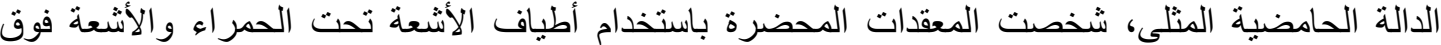
البنفسجية- المرئية، التحليل الدقيق للعناصر(C.H.N) وتقنية الامنصاص الذري اللئية اللهبي، فضلا عن قياسات

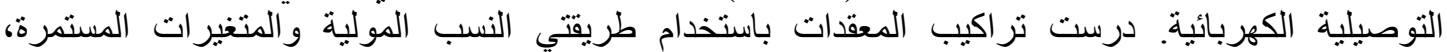

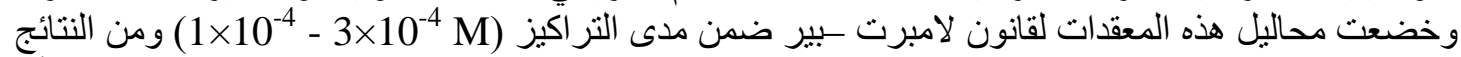

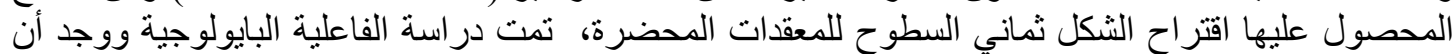

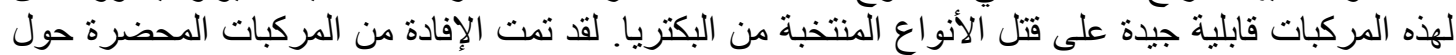

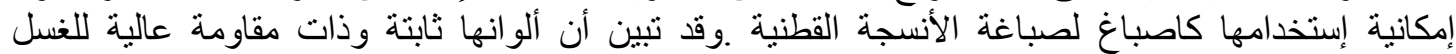
و المنظفات ولضوء الثمس.

الكلمات المفتاحية: المعقدات، تحضير اصباغ، الفاعلية البايولوجية. 